Ільєнко О. П., здобувач *

Головне управління Держкомзему у Полтавській області

\title{
ЗМІНА ТЕМПЕРАТУРИ ПОВЕРХНІ СІЛЬСЬКОГОСПОДАРСЬКИХ УГІДЬ ЗА ДАНИМИ СУПУТНИКА LANDSAT ТМ 5
}

\section{Рецензент - кандидат сільськогосподарських наук А. А. Кочерга}

\begin{abstract}
Висвітлюсться питання визначення наявності відмінностей температури поверхні грунтів сільськогосподарських угідь, зокрема, чорноземів типових глибоких малогумусних, за допомогою теплового каналу супутника Landsat 5 (TM). Подано результати автоматизованої ідентифікації відпові-

дних показників на супутниковому знімку за 25 вересня 2010 року із використанням моделі енергетичного балансу (SEBAL) на території Кіровської сільської ради Полтавського району Полтавської області. Результати дослідження лягли в основу виявлення залежності температури поверхні грунтів від їх типу й родючості.
\end{abstract}

Ключові слова: теплове випромінювання, атмосферна корекиія, Landsat 5 (TM), SEBAL, RED.

Постановка проблеми. За умов інтенсивного землеробства в країні існує гостра потреба у своєчасному моніторингу стану грунтів сільськогосподарських угідь. Одним із важливих аспектів даного питання є дослідження можливості одержання інформації про грунти із багатоспектральних супутникових знімків. Така інформація дала б змогу оптимізувати сільськогосподарське виробництво шляхом виявлення процесів погіршення стану грунтів.

У даній статті наведені результати аналізу знімку американського супутника Landsat 5 (TM), хоча необхідні для таких досліджень дані можна також отримувати від нині діючого українського супутника Січ-2 [10].

Наукові дослідження минулих років показали чітку залежність теплових властивостей грунтів і ïх типів $[1,5,6]$. У рамках першого етапу дослідження даної проблеми було проведено ідентифікацію змін теплового випромінювання на різних ділянках поверхні сільськогосподарських угідь Полтавської області за методом SEBAL, який передбачає пряму оцінку значень точок (пікселів) теплового знімка поверхні грунту [3].

Аналіз основних досліджень і публікацій, у яких започатковано розв'язання проблеми. Відомо, що кожне фізичне тіло має певні, при- таманні лише йому теплові властивості. До теплових властивостей грунтів відносяться теплопоглинальна здатність, теплоємність і теплопровідність.

Теплопоглинальна здатність - здатність грунтів поглинати й утримувати енергію сонця. Характеризується величиною альбедо - кількістю сонячної радіації, відбитою поверхнею грунту i вираженою в відсотках від сумарної сонячної радіації. Альбедо коливається від 8 до $30 \%$ і залежить від кольору грунтів, їх структурного стану, вологості, характеру поверхні. Темні грунти поглинають більше енергії, ніж світлі, вологі більше, ніж сухі.

Теплоємність - здатність грунту поглинати тепло; кількість тепла в калоріях, необхідна для нагрівання $1 г$, або $1 \mathrm{~cm}^{3}$ грунту на $1{ }^{\circ} \mathrm{C}$. Теплоємність залежить від мінералогічного і гранулометричного складу грунту, вмісту в ньому органічної речовини, вологості. Вологий грунт має більшу теплоємність, аніж сухий, а глинистий більшу, ніж піщаний.

Теплопровідність - здатність грунту проводити тепло. Теплопровідність залежить від гранулометричного, хімічного складу, гумусованості, щільності, пористості, ступеня зволоження грунту. Мінеральна частина грунту проводить його ліпше, ніж органічна, вода - краще, ніж повітря.

Тепловий режим - сукупність і визначена послідовність явищ теплообміну в системі приземного шару «повітря - рослини - грунт - підстилаюча порода», а також сукупність процесів теплопереносу, теплоакумуляції та теплорозсіювання у грунті. Температура грунту - досить динамічна величина. Рівновага між температурою атмосфери і 0-5 см шару грунту встановлюється протягом декількох хвилин. Тепловий і водний режими тісно взаємопов'язані. Переходи води 3 однієї фази в іншу залежать від теплового режиму. Добова динаміка температури різко виражена у перших півметра грунту. Вдень тепловий потік спрямований зверху вниз; вночі - знизу наверх.

* Керівник-доктор сільськогосподарських наук, професор П. В. Писаренко 


\section{СТОРІНКА МОЛОДОГО ВЧЕНОГО}

Максимум температури спостерігається на поверхні грунту вдень, близько 13 год., мінімум перед сходом сонця. Зі зростанням глибини амплітуда коливань температури знижується, i добова динаміка на глибині 50 см практично повністю затухає. На добовий режим грунтів суттєво впливають клімат і погодні умови місцевості, вологість грунтів, їх гранулометричний склад, стан поверхні, кількість органічної речовини, забарвлення, рельєф, наявність снігового покриву тощо. Наприклад, рослинний покрив, важкий грансклад зменшують добові амплітуди коливань температури $[1,5,6]$.

Очевидно, що між фізичною структурою грунту і його тепловим режимом існує певна залежність. Для перевірки даної гіпотези необхідно дослідити однотипні грунти на незначній території, щоб досягти максимальної однорідності температури повітря. Вкрай важливо, щоб значення температури поверхні грунтів були одержані в один і той же час.

Одним із можливих варіантів вирішення вищеозначеної проблеми є використання шостого (RED, теплового інфрачервоного) каналу знімальної апаратури супутника Landsat 5 (Thematic Mapper). Тепловий інфрачервоний канал $є$ чутливим до випромінювання 3 довжиною хвилі 10,4-12,5 $\mu \mathrm{m}$ i має роздільну здатність $120 \mathrm{M} /$ піксель. Ширина смуги огляду супутника

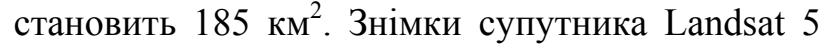
(TM) розповсюджуються геологічною службою США (USGS) на своєму сайті безкоштовно [8, 9].

Мета досліджень та методика їхнього проведення. Метою даного дослідження є ідентифікація змін теплового випромінювання на різних ділянках поверхні сільськогосподарських угідь за допомогою багатоспектрального знімка супутника Landsat 5 (TM) за 25 вересня 2010 року. Відповідна дата створення знімків обрана як оптимальна між осінньо-зимовою надмірною хмарністю, що перешкоджає зніманню території супутником, i незначним, уже на той час, покриттям грунту сільськогосподарськими культурами, які заважають ідентифікувати іншу рослинність.

Супутниковий знімок охоплює центральну i північну частини Полтавської області. Для проведення дослідження обиралися сільськогосподарські угіддя загальною площею 1557,84 га на території Кіровської сільської ради Полтавського району Полтавської області.

Вищеозначену досліджувану територію обрано через майже суцільну однотипність грунтів сільскогосподарських угідь, - тут переважають чорноземи типові глибокі малогумусні.

На досліджуваній території виділено 13 ділянок не вкритих рослинністю з однотипними грунтами із площею від 43,52 до 236,36 га (рис. 1).

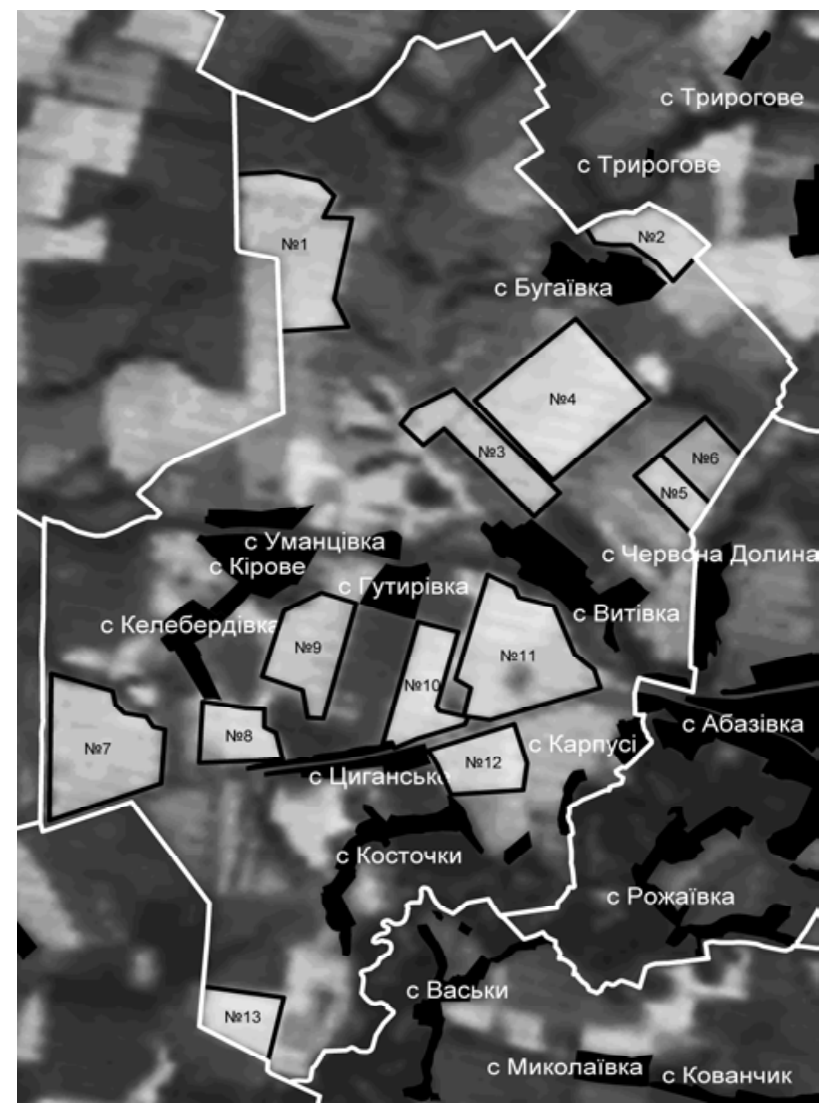

Рис. 1. Тепловий супутниковий знімок досліджуваної території з нанесеними межнами Кіровської сільської ради, населених пунктів і дослідних ділянок

Відсутність рослинності на досліджуваних ділянках було ідентифіковано за показниками індексу $N D V I$, який виявляє будь-яку рослинність на поверхні землі й розраховується 3 використанням інших спектральних каналів супутника за формулою:

$$
N D V I=\frac{N I R-R E D}{N I R+R E D},
$$

де: $N I R$ - поглинання ближньої інфрачервоної області спектру;

$R E D$ - поглинання червоної області спектру.

Відповідно до цієї формули, щільність рослинності $(N D V I)$ в певній точці зображення дорівнює різниці інтенсивності поглинутого світла в червоному й інфрачервоному діапазоні, діленою на суму їх інтенсивності.

Для проведення дослідження було обрано модель енергетичного балансу (SEBAL), $з$ допомогою якої обчислюється значення теплового потоку грунту на кожен піксель супутникового зо- 


\section{СТОРІНКА МОЛОДОГО ВЧЕНОГО}

браження теплового спектру. Суть даної моделі визначає наступна формула:

$$
R_{n}-G=H-L E \text {, }
$$

де: $R_{n}$ - баланс випромінювання, $G$ - тепловий потік грунту, $H$ - виважений тепловий потік грунту і $L E-$ прихований тепловий потік [3].

У разі використання вищеозначеної моделі слід обов'язково враховувати вплив атмосферного повітря над досліджуваною територією, що частково викривляє теплове випромінювання. Щоб усунути дане викривлення, необхідно здійснити атмосферне корегування супутникового зображення [9].

Матеріали супутникової зйомки опрацьовано 3 використанням програмного забезпечення ITT ENVI $4.7[2,4,7]$.

Результати досліджень. У ході досліджень за даними теплового супутникового знімка було розраховано значення температури для поверхні грунтів 13-и дослідних ділянок і одержані наступні результати (див. табл.).

Iз даних таблиці видно, що значення температури поверхні досліджуваних ділянок коливається в межах 25,1 до $33,6{ }^{\circ} \mathrm{C}$. Це свідчить про певні відмінності між поверхневим шаром грунту цих ділянок. Середньозважений за площею ділянок показник температури становить $28,0{ }^{\circ} \mathrm{C}$ - за результатом аналізу знімка 3 атмосферним корегуванням і $30,6{ }^{\circ} \mathrm{C}$ - без відповідних корегувань.

Встановлено, що значення температури, розраховані на основі теплового зображення без атмосферного корегування, відрізняються від показників, одержаних із корегованих зображень всередньому на $+2,6{ }^{0} \mathrm{C}$. Це свідчить про необхідність атмосферних корегувань супутникових знімків перед їх використанням у ході досліджень.

Існує потреба у проведенні більш детального дослідження із використанням даних наземного моніторингу типу та якості грунтів. У таблиці наведені узагальнені по кожній із ділянок показники температури. У випадку з кольоровим картографуванням прояву значень даного показника можна спостерігати його зміну в межах кожної ділянки у заданому діапазоні.

\section{Висновки:}

У ході дослідження шляхом супутникового моніторингу були виявлені зміни температури поверхні грунту в межах 25,1 до $33,6{ }^{0} \mathrm{C}$ на сільськогосподарських угіддях загальною площею 1557,84 га, що розташовані на території Кіровської сільської ради Полтавського району Полтавської області. За результатами дослідження одержано цифрову мапу змін температури поверхні досліджуваних ділянок.

Атмосферні корегування мають істотний вплив на результати аналізу теплового супутникового знімка.

Надалі доцільно провести більш детальні дослідження з урахуванням даних наземного моніторингу типу та якості грунтів.

Супутникові знімки, що мають більшу роздільну здатність, дають змогу одержувати більш точні результати досліджень.

Результати оцінки температури поверхні трунту на досліджуваній території за даними теплового зображення супутника Landsat 5 (TM)

\begin{tabular}{|c|c|c|c|c|c|}
\hline \multirow{3}{*}{$\begin{array}{l}\text { Номер } \\
\text { ділянки }\end{array}$} & \multirow{3}{*}{$\begin{array}{c}\text { Площа } \\
\text { ділянки, га }\end{array}$} & \multicolumn{4}{|c|}{ Одержані значення температури поверхні грунту } \\
\hline & & \multicolumn{2}{|c|}{$\begin{array}{c}3 \text { поправкою } \\
\text { на вплив атмосфери }\end{array}$} & \multicolumn{2}{|c|}{$\begin{array}{c}\text { без поправки } \\
\text { на вплив атмосфери }\end{array}$} \\
\hline & & $\mathrm{K}$ & ${ }^{10} \mathrm{C}$ & $\mathrm{K}$ & ${ }^{6} \mathrm{C}$ \\
\hline 1 & 211,24 & 301,9 & 28,8 & 303,4 & 30,3 \\
\hline 2 & 75,8 & 306,7 & 33,6 & 307,7 & 34,6 \\
\hline 3 & 104,82 & 304,1 & 31,0 & 305,6 & 32,5 \\
\hline 4 & 236,36 & 299,6 & 26,5 & 301,7 & 28,6 \\
\hline 5 & 43,52 & 299,4 & 26,3 & 301,6 & 28,5 \\
\hline 6 & 58,55 & 300,1 & 27,0 & 302,2 & 29,1 \\
\hline 7 & 196,79 & 300,0 & 26,9 & 302,3 & 29,2 \\
\hline 8 & 66,71 & 301,2 & 28,1 & 303,6 & 30,5 \\
\hline 9 & 114,25 & 298,2 & 25,1 & 301,5 & 28,4 \\
\hline 10 & 92,5 & 300,5 & 27,4 & 304,2 & 31,1 \\
\hline 11 & 208,36 & 302,4 & 29,3 & 306,3 & 33,2 \\
\hline 12 & 80,33 & 299,2 & 26,1 & 303,2 & 30,1 \\
\hline 13 & 68,59 & 302,5 & 29,4 & 306,9 & 33,8 \\
\hline \multicolumn{2}{|c|}{$\begin{array}{c}\text { Середньозважене } \\
\text { значення за площею ділянок }\end{array}$} & 301,1 & 28,0 & 303,7 & 30,6 \\
\hline
\end{tabular}




\section{БІБЛІОГРАФІЯ}

1. Назаренко I. І., Польчина С. М., Нікорич В. А. Грунтознавство: Підручник. Чернівці: КнигиXXI, 2004. - C. 157-159.

2. Посібник користувача програмного комплексу ITT ENVI [Електронний ресурс]. - Режим доступу:

http://www.ittvis.com/ProductsServices/ENVI/Tutor ials. aspx.

3. Bastiaanssen, WGM, Menenti, M, Feddes, RA \& Holtslag, AAM, «A remote sensing surface energy balance algorithm for land (SEBAL) 1. Formulation», Journal of Hydrology, 1998. - P. 198-213. 4. Canty M. J. Image Analysis and Pattern Recognition for Remote Sensing with Algorithm in ENVI/IDL, Forschungszentrum JuËlich GmbH, 2005. - P. 69-77.

5. Gillies R. R. \& Carlson T. N. Thermal remote sensing of surface soil water content with partial vegetation cover for incorporation into climate models. J. of Applied Meteorology. - 1995, №34. P. 745-756.

6. Hill J., Mégier J. \& Mehl W. Land degradation, soil erosion and desertification monitoring in Mediterranean ecosystems. Remote Sensing Reviews. 1995. - №12. - P. 107-130.

7. Сайт географічних інформаційних систем та дистанційного зондування [Електронний ресурс]. Режим доступу: http://gis-lab.info/qa/ndvi.html.

8. Сайт Геологічної служби США [Електронний pecypc]. - Режим доступу: http://glovis.usgs.gov/.

9. Сайт програми Ландсат [Електронний ресурс]. - Режим доступу: http://landsat.usgs.gov/.

10.Сайт Центру прийому і обробки спеціальної інформації та контролю навігаційного поля [Електронний ресурс]. - Режим доступу: http://dzz.gov.ua/CPOSI/sich_2_reklama.php 